\title{
MIR1-1 Gene
}

National Cancer Institute

\section{Source}

National Cancer Institute. MIR1-1 Gene. NCI Thesaurus. Code C80710.

This gene is involved in the regulation of gene expression and plays a role in development

of lung and hepatocellular carcinomas, cardiomyopathy, cardiac hypertrophy and coronary artery disease. 